\title{
A SOCIO-HISTORICAL PERSPECTIVE ON THE AMAZIGH (BERBER) CULTURAL MOVEMENT IN NORTH AFRICA
}

\section{Abderrahman EL AISSATI}

Babylon

Tilburg University

5000 Le Tilburg

The Netherlands

e-mail: aissati@uvt.nl

\section{SUMMARY}

A socio-historical perspective on the Amazigh (Berber) Cultural Movement in North Africa

North Africa has known various colonizations which in contact with indigenous ones have given the area a special character. One continuing presence since antiquity is that of the Berbers, or the Imazighen, the indigenous population of the area. In this article an attempt is made to shed light on the status of the language and culture of the Imazighen, and in particular on the recent calls for official recognition of the Amazigh language in the constitutions of the two 
countries with the highest presence of Imazighen, namely Morocco and Algeria. Although some recent developments, like the teaching of the Amazigh language in primary schools, give reason enough to be optimistic about the future of the indigenous language and culture, $a$ closer look at the ideological background of pan Arab-nationalists casts doubts on any serious government intentions to guarantee the maintenance and development of the Amazigh language and culture. This ideology will be brought to light by contrasting the constitutional rights that some Muslim and/or African countries grant to their citizens who speak different languages than the official one(s).

Key words: Amazigh identity, Amazigh Language, Berber, culture, linguistic rights, minority languages, pan-Arabism

\section{A HISTORICAL SKETCH OF THE REGION}

It is commonly accepted in the literature on North African history that the indigenous people of this area are the Berbers, or the Imazighen, as they refer to themselves. The area in question extends from the Siwa oasis near the Egyptian and Lybian borders to the Canary Islands in the Atlantic Ocean and from the southern coast of the Mediterranean to the Northern areas of Mali, Niger and Burkina Faso. ${ }^{49}$ The current number of Imazighen, or rather speakers of one of the Amazigh varieties, has remained a matter of estimates. Most authors cite figures around $25 \%$ of the Algerian population (with highest concentrations in mountainous areas like Kabylia, the Aures mountains (Chaouia) and the Mzab), around $45 \%$ of the Moroccan population (highest concentration in the Rif area, the Atlas Mountains, and the Sous Valley), $1 \%$ of the Tunesian population (mostly in the island of Djerba), a few thousand in Lybia (mostly in Jbel Nefousa), and around 1,000,000 in the Southern part of Algeria and Northern parts of Mali and Niger, commonly designated as the Tuaregs. ${ }^{50}$ The

\footnotetext{
${ }^{49}$ See for example Camps, G. (1995), Brett \& Fentress (1996)

${ }^{50}$ Brett \& Fentress. The Berbers. Oxford: Blackwell Publishers, (1996: 3)
} 
Major language groups of the area are Tarifit, Tamazight and Tashelhit in Morocco (from North to South), Kabyle and Choaui varieties in Algeria. The absence of a linguistic atlas of the region makes again a matter of who is counting and what is being counted (e.g. two varieties of the same language can be defined as two languages). The Amazigh language has been classified as descendant of the Afro-Asiatic branch which includes Semitic languages, Ancient Egyptian and its 'descendant' Modern Coptic, Kushitic languages, etc. ${ }^{51}$

North Africa has been the locus of various colonizations, and interactions with 'outsiders', from the founding of Carthage around $814 \mathrm{BC}$ to the arrival of the French and Spanish colonizers in the twentieth century. The Muslim presence, starting around 647 A.D., has become the most significant one. ${ }^{52}$

The recent history of North Africa is marked by the presence of different colonial powers, with the French one as the one that has left a very lasting impact on the region. The French effectively invaded Algeria in 1830, and in 1907 occupied Oujda and Casablanca, before the beginning of the protectorate period in 1912, following an agreement with the Moroccan Sultan. The Northern and southern parts fell under Spanish authority.

During the protectorate period, an event of paramount importance in the modern history of Morocco, which was to be exploited by the nationalist movement of this country, is the elaboration of a decree in 1930. This decree, signed by the then king of Morocco, Mohamed V, stipulated that the areas with Berber as the dominant language -mostly rural areas- were entitled to carry on their tribal law system (droit coutumier), which had been the practice among the Berber tribes for centuries. What the French did was simply formalize these practices by law. This decree was seen by the pan-Arab nationalists as the ultimate attempt by France to separate Berbers from Arabs. The significance of this decree in the history of the Berber cultural

${ }^{51}$ See http://www.ethnologue.com.

52 For an overview of the History of the region in English see Brett, Michael \& Elizabeth Fentress 1997. The Berbers. London: Blackwell Publishers. 
movement is a major one. Berber activists will have to face charges of attempting to recreate this decree whenever they claim their identity as a different one from the (pan-) Arab one! This decree which will also become popularized as the 'dahir berbère' (the Berber decree), suggesting that it was elaborated by the Berbers themselves, and not by agreement between the king of Morocco and the French masters. These charges are usually accompanied by a reminder that the population of Arab-dominant areas demonstrated against it, and were calling for a unity between the Berbers and Arabs.

In Algeria a similar crisis emerged in 1948-49 when the French federation of the "Parti du peuple algérien" (PPA) and the "Mouvement pour le triomphe des libertés démocratiques" (MTLD) criticized the arab-orientation of the party in its definition of the Algerian nation, and suggested the inclusion of the Berber identity of Algeria. The response of the PPA-MTLD leadership was the exclusion of a number of members from the federation (Haddadou, 2003).

\section{THE BERBERS AFTER INDEPENDENCE}

The stride against colonization in Morocco and Algeria was led at two different and conflicting fronts. The round tables and discussion sessions between 'representatives' of national interests and the colonizing administration were led by the urban, mostly a non-Berber elite, while the fighting on the ground and the armed resistance was more the business of the Berbers (The Amazigh manifest and other references). Interestingly, even the French were called upon at the beginning of the twentieth century to help subdue the Berber tribes that were not under the central (Makhzen) authority. Their arrival was welcomed by the Makhzen as the saviours from the local 'anarchy' (see the Berber manifest of March 1, 2000).

As the independence was granted to Morocco in 1956, the first task was to draw the lines of a constitution. In the constitution of 1962, it was made clear that Arabic is the official language of the country, which is defined as a Muslim state. It is rather strange that not a single mention is made of Berber, either as a language or as a part of the 
identity of the country. Moreover, no provision whatsoever was made to the millions of Berber monolinguals in their interaction with the state. For example, nothing was said about the right to use one's native language in courts of law, or the right to have an interpreter, etc.

To give an idea about how other African countries have dealt with their multicultural background, here are a few excerpts from constitutions of some of these countries.

The constitution of the Democratic Republic of Congo, drafted in 1992 (http://www.constitution.org/cons/natlcons.htm) defines French as its official language, and Lingala and Munukutuba as functional national languages (article 3). Article 35 of the same constitution states that "Citizens shall possess a right to culture and to the respect of their cultural identity". All the communities composing the Congolese Nation shall possess the freedom to use their languages and their own culture without prejudicing those of others.

The republic of Malawi grants citizens "the right to use the language and to participate in the cultural life of their choice" and states that "Every person who is detained, including every sentenced prisoner, shall have the right to be informed promptly in a language which he or she understands of the reason for his or her detention (Constitution of 1994, chapter 3, articles 26 and 40).

The republic of Senegal defines French as its official language, Diola, Malinké, Pular, Sérère, Soninké and Wolof as its national languages, as well as any other national language which will be codified. (Constitution adopted on January 7, 2001, article 1: www.gouv.sn/textes /constitution.pdf).

Article 22 of the same constitution makes it a duty of "all national institutions, private or public, to participate in the national efforts to alphabetize their members and to take part in the national effort of achieving literacy in one of the national languages."

A last example will be quoted from the republic of South Africa.

The constitution of post-Apartheid regime in this country, states in Article 1 that "The official languages of the Republic are Sepedi, Sesotho, Setswana, siSwati, Tshivenda, Xitsonga, Afrikaans, English, isiNdebele, isiXhosa and isiZulu." It is obvious that the official status of these languages raises their status in that the government will have 
the duty to publish its documents and to conduct business in any of these languages.

To end this illustration, it should be pointed out that constitutions do not reflect the reality of the status of the language or of the national cultures, but they do provide a minimum protection for these. This illustration is meant to show differences between countries in dealing with their multilingual identities.

\section{BERBER AND ISLAM}

The deliberate ignorance of anything Berber by the Moroccan and Algerian constitutions cannot be explained by the adherence of the countries to Islam as the religion of the state. Islam, through its sacred book the Coran, makes it clear that God created people of different races and tongues as a sign of His sovereignty. The sura of The Romans, verse [30.22] reads as follows: "And one of His signs is the creation of the heavens and the earth and the diversity of your tongues and colors; most surely there are signs in this for the learned." Multilingualism in the view of Islam is certainly not a punishment of humanity, as the fall of the Tower of Babel is interpreted in the Bible (Umberto Eco, 1993).

Other predominantly Muslim countries like Iran, Indonesia and Afghanistan function in their own national languages.

An example from Iran can illustrate the point being made. The constitution of this country after its Islamic Revolution in 1979 states under article 15: "The official language and script of Iran, the lingua franca of its people, is Persian. Official documents, correspondence, and texts, as well as text-books, must be in this language and script. However, the use of regional and tribal languages in the press and mass media, as well as for teaching of their literature in schools, is allowed in addition to Persian. "Because of its Islamic adherence, Iran provides for Arabic under article 16: "Since the language of the Qur'an and Islamic texts and teachings is Arabic, and since Persian literature is thoroughly permeated by this language, it must be taught on elementary level, in all classes of secondary school and in all areas of study." 
Indonesia, in article 36 of its constitution states that "The Language of the State shall be the Indonesian Language", but also that "regional languages which are well preserved by the people, such as the Javanese, Sundanese, Madurese and other languages, will be respected and preserved by the state. Since these languages are also part of the Indonesian culture." Article 114 provides for the right of individuals not understanding the language in which they are being addressed to use their mother tongue in addressing the court, and to obtain documents of the case through an interpreter.

(http://asnic.utexas.edu/asnic/countries/indonesia/ConstIndonesia.html).

Afghanistan has Pashtu and Dari as official languages among the national languages of the country (constitution of 1990, article 8). The state has also the duty to "adopt necessary measures for the growth of culture, language and literature of the people of Afghanistan as well as preserve and develop the worthy cultural, traditional, linguistic, literary and folkloric legacy of all nationalities, clans and tribes."

The main factor working against recognizing Berber in the constitutions of Morocco and other North African countries is the panArab nationalism, which has always advocated unity among Arab nations. This unity was considered by many as the only way to face up the colonizing nations. The following excerpt from the preamble of the constitution of the Republic of Syria (1973) illustrates this ideology:

"The Arab nation managed to perform a great role in building human civilization when it was a unified nation. When the ties of its national cohesion weakened, its civilizing role receded and the waves of colonial conquest shattered the Arab nation's unity, occupied its territory, and plundered its resources. Our Arab nation has withstood these challenges and rejected the reality of division, exploitation, and backwardness out of its faith in its ability to surmount this reality and return to the arena of history in order to play, together with the other liberated nations, its distinctive role in the construction of civilization and progress. With the close of the first half of this century, the Arab people's struggle has been expanding and assuming greater importance in various countries to achieve liberation from direct colonialism." 
In all likelihood, the reference to the glorious past would have been more accurate if it were made to Muslims instead of Arabs. The insistence on the Arab element is simply an expression of denial of all other nations that have driven Islam towards a golden age. The type of ideology expressed in the preamble of the Syrian constitution is still alive among many Moroccans. The fear from "weakening the ties of the national cohesion" and the nostalgia for a glorious"Arab past" are usually behind the attacks against the Berber movement.

\section{RECENT DEVELOPMENTS IN THE BERBER CULTURAL REVIVAL}

The call for the recognition of a distinct Berber identity has been gaining popularity especially after the independence of Morocco and Algeria. One of the first non-governmental institutions to specialize in promoting Berber culture and language is the Académie Berbère, founded in Paris in 1967 by a group of Amazigh activists. The Académie Berbère was an eye-opener for many Berbers. Its main goal was to promote the Berber culture and conduct research on the Berber culture and civilization. Its founding outside Algeria was most likely due to the Algerian restrictions on non-governmental and cultural organizations (operative until the beginning of the 1990's).

In the same year, "L'Association Marocaine de la Recherche et de l'Echange Culturel (The Moroccan Association for Research and Cultural Exchange)" was founded in Morocco, with goals similar to those of the Académie Berbère.

Among other things subsequent developments will put more emphasis on calls for identity recognition and linguistic rights. An event of paramount importance in the modern struggle of the Berber movement is the Berber Spring (Tafsut n Imazighen) of 1980. The Algerian anthropologist Mouloud Mammeri was invited to give a talk on March 10 th on Kabyle poetry. The cancellation of this lecture by the government authorities led to wide-spread protests and clashes between supporters of the Berber movement and law enforcement agents. Since then, this event has gained the status of a symbol of the fight for a Berber identity, and is celebrated by Algerians, Moroccans, and other Berbers of North Africa, both at home and in immigration countries. 
The creation in 1990 of two departments for the study of Berber language and culture in Algeria certainly opened more doors to students interested in this field. The universities of Tizi Ouzou (since 1990) and Bejaia (since 1991) have been responsible since then for a number of graduations in the field of Berber language and literature.

The call for recognition of Berber cultural and linguistic rights will be formalized in a document signed initially by six cultural associations in Agadir (Morocco) in 1991. This document, known as "la Charte d'Agadir", is a protest against the marginalization of Berber and puts forth demands like the recognition of Berber as a national language by the Constitution, its standardization and its inclusion in schooling. (http://www.mondeberbere.com/mouvement:charte.htm).

On May $1^{\text {st }}, 1994$, during the celebrations of the international Labor Day, a group of Berber activists from the Cultural Association Tilelli in Errachidia, Morocco, were arrested on charges of disrupting public order. The activists were carrying banners with slogans written in Tifinagh (see IRCAM alphabet below). This event gained international recognition and also became a symbol of the Berber struggle (see Donnet, 1995).

The first time Berber was publicly dealt with by the highest authorities in Morocco was on August $20^{\text {th }}$ 1994. King Hassan II spoke of the importance of including Berber in the Moroccan education system. This was seen as a major support for the Berber movement, seeing that if the king himself is for the teaching of Berber, this would mean that it forms no threat to the established order. However, this has not been realized until September 2003 (see note 2).

In 1995, following a year of school strikes throughout the Kabyle area, known as "la grève du cartable" (school-bag strike) the president of Algeria, Liemin Zeroual announced the creation of a "Haut Commissariat à l'Amazighité" (HCA). Among the tasks of the HCA are language planning, developing a policy for teaching Berber and for its use in public spheres.

The scope of the Berber movement was considerably enlarged by the founding in 1995 of the "Congrès Mondial Amazigh (CMA)", a 
transnational non-governmental institution which aims at "defending and promoting the cultural identity of the Berber nation and supporting its development in all domains, inside and outside the Tamazgha [North Africa, including the Canary Islands, (A.E)] and for an official recognition of the Amazigh identity". (http://www.congresmondial-amazigh.org/). The members of this organization are exclusively cultural associations, from North African countries and immigration countries.

More recently, in October 2001, the first higher institute for research on Berber was created in Rabat, Morocco, by royal decree, under the name of "Institut Royal de la Culture Amazighe (IRCAM)." This institute is the only one across Morocco with an official mandate to carry out research on Berber, elaborate school manuals, and deal with issues related to Berber.

\section{NEW HOPE FOR BERBER REVIVAL: BERBER AT SCHOOL}

As pointed out earlier, the decision to include Berber in primary school education was announced in 1994. This promise was supposed to see the day in September 2003. About 300 schools all over the country of Morocco will take part in this experiment, and about 1000 school teachers will receive a special training to teach Berber. ${ }^{53}$

The script that will be used in teaching Berber is Tifinagh, an indigenous North African script that was used in numerous inscriptions, found in different parts of North Africa. Tifinagh is mostly used for its symbolic value. It is almost impossible to find a newspaper, journal, or web site which does not use a few letters from this script (see illustration of the alphabet officially adopted by the IRCAM; this alphabet is also accepted by (ISO) the International Organization for Standardization).

\footnotetext{
${ }^{53}$ Speech of Moroccan Minister of Education at the Symposium on teaching Berber, organized by the Fondation Banque Marocaine pour le Commerce Extérieur, Casablanca, June 172003.
} 
The other candidates for writing in Berber are the Arabic script and the Latin script. Both are still in use. There has been no major survey to help the interested parties see what the preferences of the users might be. Two small scale surveys were published previously, in which it became clear that among Berber activists the Tifinagh script and the Latin script were by far the favorites. ${ }^{54}$

While both Algeria and Morocco have implemented Berber in their education systems, there are three major differences between the policy of these two states.

First, Berber in Morocco is a compulsory subject while in Algeria it remains an elective class.

The second difference has to do with the areas where Berber is taught. In Morocco, the idea is to generalize teaching Berber to the whole kingdom, thus allowing also native speakers of Moroccan Arabic and other languages to learn this language. In Algeria, Berber teaching is limited to the areas where there is a high concentration of Berber speakers.

The third major difference has to do with the alphabet chosen to teach Berber. Morocco has opted for the Tifinagh alphabet (see illustration) and Algeria has chosen the Roman (Latin) script.

${ }^{54}$ One survey was conducted by the journal Tifinagh, Rabat, and the other one by the Adrar Cultural Association (the Netherlands), published in Adrar-Nieuwsbrief. 


\begin{tabular}{|c|c|c|c|c|c|}
\hline 1 & 。 & o[ol & $\mathrm{a}$ & aman & water \\
\hline 2 & $\theta$ & $\theta_{\circ} \theta_{\circ}$ & $b$ & baba & my father \\
\hline 3 & C & E.co & C & maca & but \\
\hline 4 & $\wedge$ & $\Lambda_{0}$ & d & da & here \\
\hline 5 & 8 & $18++0$ & $\mathrm{e}$ & netta & he \\
\hline 6 & H & OH.O & f & afar & leaf \\
\hline 7 & X & oXllo & $\mathrm{g}$ & agla & property \\
\hline 8 & (1) & Фபு & $\mathrm{h}$ & hwa & go down \\
\hline 9 & 8 & \{ㅔ연 & $\mathrm{i}$ & ilef & pig \\
\hline 10 & $I$ & $I \Theta \& \wedge$ & j & jbed & pull \\
\hline 11 & $\mathbf{R}$ & oroll & k & akal & dirt \\
\hline 12 & H & "181 & I & lul & be born \\
\hline 13 & {[} & Cols & $\mathrm{m}$ & mani & where \\
\hline 14 & 1 & +घs & $\mathrm{n}$ & tini & dates \\
\hline 15 & $\dot{H}$ & $\mathrm{~h} \wedge \mathrm{O}$ & $\varepsilon$ & $\varepsilon d u$ & pass (v.) \\
\hline 16 & $\Lambda$ & $\Lambda_{0} \Lambda_{0}$ & $\mathrm{~h}$ & hada & touch (v.) \\
\hline 17 & $\boldsymbol{Z}$ & REC & $q$ & qim & sit down \\
\hline 18 & 0 & .OE & $r$ & ari & write (v.) \\
\hline 19 & $\odot$ & ๑ㄴ & $\mathbf{S}$ & sew & drink (v.) \\
\hline 20 & + & +घnk & $t$ & tili & shade \\
\hline 21 & : & 8n & $\mathrm{u}$ & ul & heart \\
\hline 22 & $\varphi$ & . TO8E & $\gamma$ & ayrum & bread \\
\hline 23 & $\sqcup$ & 나에 & w & awal & speech \\
\hline 24 & $x$ & $+\Sigma X \odot \varepsilon$ & $x$ & tixsi & ewe \\
\hline 25 & $s$ & OSAE & $y$ & aydi & dog \\
\hline 26 & $\boldsymbol{*}$ & 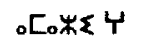 & $z$ & amazi $\gamma$ & Berber \\
\hline 27 & ※ & 。米Uг & Z & aẓli & beauty \\
\hline 28 & $Q$ & ๑TQD & $r$ & ayraw & sleeve \\
\hline 29 & $E$ & 。[\&EE。 & $\mathrm{t}$ & amețța & tear $(\mathrm{n})$. \\
\hline 30 & ○ & G\&E & $\mathbf{S}$ & șuḍ & blow (v.) \\
\hline 31 & $E$ & E\&ப & d & dew & fly (v.) \\
\hline 32 & $Z^{u}$ & $\Sigma X^{\prime} X^{\prime \prime}$ & $\mathrm{g}^{\circ}$ & $\operatorname{ig}^{\circ} g^{\circ} a$ & kneeding \\
\hline 33 & $\mathbb{R}^{\sim}$ & $+\sum R^{2} R^{\prime} O_{0}$ & $\mathrm{k}^{\circ}$ & tik ${ }^{\circ}{ }^{\circ} r a$ & insult (n.) \\
\hline
\end{tabular}




\section{CONCLUSION}

A final note about the prospects of the Amazigh language and culture in North Africa is in place. It is undoubtedly of paramount importance to introduce the Amazigh language into the educational systems of Morocco and Algeria. In fact, teaching a minority language is a crucial measure to ensure its survival (Fishman 1990). However, the continued negligence of a legal status for the Amazigh language seriously affects its future and diminishes its chances to be regarded as a language with an economical value.

The constitutions of the two countries with the highest Amazigh presence do not grant any rights to the speakers of this language to use it in government offices or outside with government employees. It is very likely that Morocco and Algeria will change their self-definition and recognize Berber both as a major constituent of their identity (already in the preamble to the Algerian constitution) and as an official language. This last possibility is certainly realistic seeing that Berber is now being 'moulded' into a school language, allowing it to acquire the necessary registers to fully function in formal settings (government agencies, written media, etc.).

\section{ILLUSTRATION}

The Tifinagh alphabet adopted by the Royal Institute for the Amazigh Culture.

\section{BIBLIOGRAPHY}

BRETT, M \& E. FENTRESS, The Berbers. Oxford: Blackwell Publishers, 1996

CAMPS, G., Les berbères: mémoire et identité. ( $2^{\text {nd }}$ ed.) Paris: Errances, 1995

DONNET, J., Renaissance berbère au Maroc. Le Monde Diplomatique, janvier 1995

ECO, U., 1993, "Ricerca della lingua perfetta nella cultura europea", Laterza, Rome. Translated by Fentress, J. "The search for the perfect language", Blackwell, Oxford, 1995. 
FISHMAN, J., 1990. What is reversing language shift (RLS) and how can it succeed? Journal of Multilingual and Multicultural Development 11, 5-36.

HADDADOU, 2003. L'Etat algérien face à la revendication berbère: de la répression aux concessions. In Glottopol. Revue de sociolinguistique en ligne, 1, 2003, pp.131138.

\section{WEBSITES CONSULTED}

http://asnic.utexas.edu/asnic/countries/indonesia/ConstIndonesia.html. http://www.congres-mondial-amazigh.org/ http://www.constitution.org/cons/natlcons.htm http://www.gouv.sn/textes/constitution.pdf http://www.mondeberbere.com/mouvement.charte.htm http://www.tawiza.net

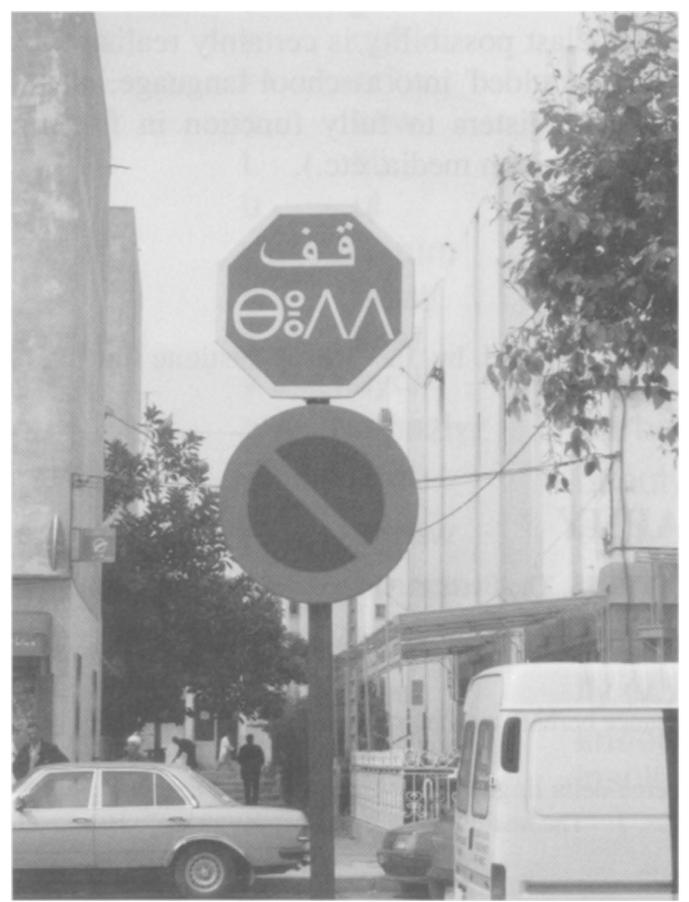

